University of Nebraska - Lincoln

DigitalCommons@University of Nebraska - Lincoln

\title{
Export Promotion as a Development Strategy: Evidence from Selected Southeast Asian Countries and Lessons for Ghana
}

\author{
Ohenewaa B. Newman \\ Akenten Appiah-Menka University of Skills Training and Entrepreneurial Development, \\ nohenewaa@gmail.com
}

Follow this and additional works at: https://digitalcommons.unl.edu/jade

Part of the Econometrics Commons, Growth and Development Commons, International Economics Commons, Political Economy Commons, Public Economics Commons, and the Regional Economics Commons

Newman, Ohenewaa B., "Export Promotion as a Development Strategy: Evidence from Selected Southeast Asian Countries and Lessons for Ghana" (2021). Journal for the Advancement of Developing Economies. 47.

https://digitalcommons.unl.edu/jade/47

This Article is brought to you for free and open access by the Institute for the Advancement of Developing Economies at DigitalCommons@University of Nebraska - Lincoln. It has been accepted for inclusion in Journal for the Advancement of Developing Economies by an authorized administrator of DigitalCommons@University of Nebraska - Lincoln. 


\title{
Export Promotion as a Development Strategy: Evidence from Selected Southeast Asian Countries and Lessons for Ghana
}

\author{
Ohenewaa B. Newman* \\ Department of Management Studies Education, Akenten Appiah-Menka University of Skills \\ Training and Entrepreneurial Development, Kumasi, Ghana
}

\begin{abstract}
Developing countries have adopted various development strategies such as import substitution industrialization (ISI) and export promotion strategies. For Latin-American and developing countries, some level of economic growth was experienced using ISI after the Second World War. However, these countries could not attain the needed economic growth, technological advancement or guarantee food security with the adoption of ISI. It led to unequal income distribution, less internal competition, and distortions of their economy, among others. The rise of export promotion strategies in the 1970s was evidenced by an impressive economic growth and a decline in poverty in jurisdictions like Taiwan, Tanzania and among the Asian Tigers. The aim of this paper is to analyze the rationale behind the adoption of export promotion strategy vis-à-vis its application, successes, and failures in some selected Southeast Asian Countries. Furthermore, the world is currently faced with COVID-19 pandemic, a dire health crisis having economic implications across the globe. This crisis has triggered countries including selected Southeast Asian economies to develop new strategies. Using literature, this paper argues that Ghana can improve its export promotion strategy by drawing lessons from these Southeast Asian countries pre and during the COVID-19 era.
\end{abstract}

Keywords: Africa, economic growth, international trade, diversification, COVID-19, developing economies

*Corresponding author: nohenewaa@gmail.com / +233248543898

\section{INTRODUCTION}

Generally, countries have viewed the promotion of exports as a medium to economic growth and it has played an integral role in development for decades. Countries especially developing countries have adopted various approaches to achieve economic growth and development ranging from import substitution industrialization and export promotion strategies. For Latin-American and developing countries, some level of economic growth was experienced by the use of Import Substitution Industrialization (ISI) also known as inward looking strategy (Ackah et al., 2014). Steel (1972) explains ISI policy as an elimination of imports in a country to allow local production of such products. Under import substitution, formerly imported commodities are manufactured in established local production industries (Baer, 1972). The purpose of eliminating the importation of some commodities under ISI is to increase investment in that country in due course (Baer, 1972). Under the world division of labor, economically less developed regions, including Latin America, most areas of Asia and Africa were exporting food and raw materials to areas like Europe and the United States. In a bid to break away from this division, less economically developed nations 
adopted ISI to reduce their dependence on more economically developed countries. Industrialization in these countries that adopted ISI led to their economic growth. Some have confirmed that ISI which is an inward looking strategy was necessary for countries but it could not help them attain the needed economic development (Balassa, 1992). ISI could therefore not be sufficient to fuel economic growth, technological advancement or guarantee food security. Internal markets of the various countries were limited. Income inequality was also a consequence of ISI as well as low labor demand (Steel, 1972). Majority of the population still were saddled with poverty. For developing African countries like Kenya, Zimbabwe and Nigeria, their economy grew slowly between 1950s and early 1970s although countries like Tanzania and Botswana experienced growth reasonably (Ackah et al., 2014).

As part of development thinking, export promotion strategies were considered by countries to stimulate economic growth. Export promotion strategies comprise policy interventions including exchange rate policies (Bhagwati, 1988) to any 'specific measures that generally amount to the government bearing a portion of the private cost of production of export' (OECD, 1984). Bhagwati (1986) argues that few countries that pursued export promotion policies in defiance of prescriptions of import substitution, achieved remarkable economic success by the late 1960s. Theoretically, market failures are the justification for export promotion policies and their effectiveness may be judged by their effects in nations that adopted these policies (Lall, 1997). There was exceptional economic growth in Taiwan and Korea in the 1960s which attracted the attention of the development community by 1970 . GDP growth rate in Taiwan and Korea increased from $5.5 \%$ and $4.4 \%$ in the 1950 s to over $10 \%$ and $9.1 \%$, respectively in the $1960 \mathrm{~s}$ (Kokko, 2002). Taiwan and Korea had made market policy changes in the late 1950s and early 1960s that reduced distortions and encouraged firms to export. The remarkable growth and export performance of Taiwan and Korea in the 1960s after their changed policy produced the great interest in outward orientation and export promotion (Vaz \& Baer, 2014; Bruton, 1998). By the early 1970s, Taiwan and Korea were widely thought to be market-driven economies. Countries including Korea, Taiwan, Malaysia and Singapore by 1994 were evidence of the most rapid economic growth from exports (Lall, 1997). The economic growth in these nations resulted from shift from import substitution to export promotion policies (Kokko, 2002). It has however been argued that the evidence of the economic growth in the Asian region in the 1970s to 1990s was not spontaneous but based on some factors. There were export incentives provided by their governments to support firms. Investment in infrastructure was increased and credit was provided to enterprises at a lower rate of interest (Kokko, 2002). These countries also developed an open foreign investment regime for export promotion (Stern, 1997).

Currently, the world is faced with COVID-19 crisis which has had significant effect on health and economies around the globe (Baldwin \& di Mauro, 2020). It has caused supply chain distortions and thus has affected international trade. This paper will seek to analyze the rationale behind the adoption of export promotion strategies vis-à-vis its application, successes, and failures in some selected Southeast-Asian countries and attempts made by these economies to keep open flow of trade in COVID-19 era. This paper seeks to draw lessons for the economic growth of Ghana which is also a developing country.

\subsection{Historical Perspective of Import Substitution Industrialization (ISI)}


One of the early original proponents of ISI was List where he propounded and examined the theory of Infant Industry (List, 1841). List in his writing, was not in support of free international trade and he claimed that there was a need to protect new industries from international competitors especially in less developed countries. The basis for his argument was that protection of new domestic industries will help stimulate production and in turn, the country will attain selfsufficiency and growth (Bora et al., 2000). List's proposition has been met with divergent views. Krueger \& Tuncer (1982) argue that the doctrine put forth by List does not provide any differentiation in the industries that he seeks for their protection which then does not provide the desired results in terms of economic growth. Westphal (1982) on the other hand, argues that the protection of infant industries should be selective, and those industries should be used to promote exports. ISI may be viewed to have developed out of the Infant Industry theory. ISI has been explained to be the elimination of imports in a country to allow domestic production of such commodities (Steel, 1972). This elimination will in the long run increase investment in the said country. Developing countries generally adopt this strategy to break away from their dependence on developed nations. For the quest of economic growth and development strategy, most Latin American countries after the Second World War adopted ISI (Vaz \& Baer, 2014). Raul Prebisch, an Argentinian Economist in 1950, in a policy document called Latin American Structuralism he prepared, advanced pessimistic view of exports in international trade and outlined the need for inward looking strategies for economic development within the Economic Commission for Latin America (ECLA). With this strategy, these countries within the ECLA implemented protective policies and majored on the production of light consumer goods like food and beverages. Some of these policies included- protective tariffs, preferential import exchange rates, and cheap loans readily made available from the state etc. It may be stated that the basis for the prominence of ISI within the ECLA was because of disruption of shipping lines and decline in manufactured goods after the Second World War (Baer, 1972). ISI as a development thinking process had its shortfalls which will be explained in the next section.

\subsection{Criticisms of Import Substitution Industrialization}

There have been various drawbacks of ISI and criticisms can be classified under the following schools of thought. The Neo-Classical school of thought argues that industrialization within the ISI is only concerned with production of consumer goods which is viewed as the first and easy stage of ISI (Balassa, 1992). This stage is viewed as easy because, economic costs is low. Technology adopted to produce these consumer goods is not sophisticated. Again, there is no need to engage highly skilled labor and the size of the market is limited as producers tend to trade within the country. From this first stage, is the second stage characterized by high technology and skilled labor. Goods to be produced will be capital and intermediate goods. It was hoped that countries move from this first stage of the ISI to the second stage to achieve the best economic growth. Unfortunately, most countries which adopted ISI failed to reach the second stage. In Brazil for instance, the GDP growth rate between 1950-1955 was 6\% and by 1956-1960, it was 8\%. GDP dropped to 3\% from 1961-1965. By 1996-2000, GDP growth rate was 2\%. (Hira, 2007). The neoclassical school of thought argues that the protective policies put in place to safeguard domestic industries led to over-regulation of the market bias against exports. The consequent effect of overregulation to this school is bureaucracy and corruption. Again, high exchange rate was an effect of ISI. These countries heavily depended on import products which were mainly capital goods, and this created balance of trade issues. Baer (1972) argues that the adoption of ISI was inefficient 
when it came to developing the country with the limited and available resources. He argues that the countries practicing ISI could have attained economic growth if it had specialized in primary products which they had comparative advantage over. Again, there was indiscriminate establishment of industries which lacked specialization. Thee (1984) argues that ISI leads to distortions in the economy.

The Structuralist school of thought also argues that because these countries who adopted ISI were producing any consumer product to avoid importing, the market of these countries were limited, and it did not afford them the opportunity to expand. This among others caused unemployment and unequal distribution of income. Poverty did not decline significantly. Prebisch (1950) who advocated for ISI in Latin America admitted of the shortcomings of ISI. There were a lot of industries set up in a closed market and there was no efficient production. ISI led to no internal competition. Competition has been viewed as a launch pad to economic development.

The Neo-Marxists view the cause of inefficiency in production to be the result of colonialism and class disparity. They argue that the ISI policy tends to favor the bourgeoisie in these countries who in turn still have strong ties with the foreign powers leading to international and local disintegration (Schmitz, 1984). They argue that it is important for nations especially developing countries to have control over foreign enterprises established in their country. There is also the need to redistribute income to bridge the class inequality. It has been argued that ISI strategy has led to unequal income distribution as it is a prominent feature in pre-capitalist societies (Schmitz, 1984).

\section{THE RISE OF EXPORT PROMOTION STRATEGIES}

In the early 1970s, it had become apparent that ISI was not the best development strategy albeit its drawbacks. Job opportunities declined with slow growth of industries. Goods produced domestically within the Latin Americas especially were highly priced. These among others led to overvaluation and high exchange rates. These countries also faced balance of payment difficulties leading to devaluation of currencies (Vaz \& Baer, 2014). These countries became highly indebted, and the economy became stagnant. Some of these Latin American nations had no option than to halt the ISI strategy as that was a condition to procuring loans from IMF and World Bank (Vaz \& Baer, 2014). Export promotion strategies comprise policy interventions including exchange rate policies (Bhagwati, 1988) to any 'specific measures that generally amount to the government bearing a portion of the private cost of production of export' (OECD, 1984). Generally, these export promotion strategies entail all steps and programs focused on aiding current and potential exporters. It is argued that export promotion policies can be grouped into two streams depending on the nature of the failure. The first failure is in regard to policies which have created distortions and the second is 'structural market deficiencies in the creation of new advantages' (Lall, 1997). Export promotion strategies based on the first failure and classified as permissive policies aim to diminish macro policy mismanagement and uncertainty (Lall, 1997). The purpose of such permissive policies is to make exporting profitable and to make it cost effective for exporters. In general terms, these permissive policies would involve removing high rates of production domestically, reducing high interest rates, inflation, high taxes on exportable products, burdensome procedures, etc. Policies based on structural market deficiencies on the other hand are referred to as positive policies and they aim at addressing deficiencies caused as a result of creating 
new exportable products, promoting the use of technology, aiding small scale to launch into the international market, establishing market and distribution systems, etc. (Lall, 1997). It has been opined that the efficacy of these export promotion strategies can only be known through their effects. Presumably, rapid economic growth in some countries were as a result of export promotion strategies.

The Asian Tigers including Hong Kong, Korea, Taiwan, and Singapore have significantly had a rapid growth through exports (Severns, 2021). The 'new' Tigers including Thailand, Malaysia and Indonesia have also enjoyed rapid growth by diversification of exports. It may however be noted that all these countries have different approaches to promoting exports. A blend of permissive and positive policies was adopted by these Tigers to facilitate growth, promote free trade and diversification of exports (Severns, 2021). By late 1960s to 1970s when most countries practicing ISI were facing economic stagnation, the Tigers were experiencing high economic growth and development through export promotion. There was impressive employment growth rate and a decline in poverty rate. Taiwan and South Korea for instance, made changes to their trade policies that encouraged exports promotion and reduced price distortions. Consequently, the success of these countries generated interest in export promotion strategy across the globe. Lessons were learned by other countries including Tanzania. Tanzania, just like any other developing country in Africa also had slow growth rate as it exported mainly raw materials in the mid and early 1960s (Biersteker, 1980). By signing to the Arusha Declaration, Tanzania, changed its trade policies to be more outward rather than inward looking. It adopted what is called selective disengagement. It disengaged from its dominant economic powers and restructured its trade relations thereby achieving national reliance (Biersteker, 1980). A prominent feature in Tanzanian's trade policy was the reduction of luxury consumer imports. Tanzania's export receipts from 1970-1971 was $5.2 \%$ and by $1976-1977$, was $17.5 \%$. Tanzanian's GDP rose from 3.92 million Tanzanian shillings in 1960 to 28.27 million Tanzanian shillings by 1977 evidencing the need for export promotion (Biersteker, 1980).

There are various reasons behind export promotion strategies. First, international trade plays a role in economic development and ISI may not help a country to achieve increased economic growth and development (Bagwati, 1986). There are advantages with international exchange of goods and services including diversification of the economy, high employment rate, positive balance of payments, economies of scale etc. With exports, a country has the advantage of division of labor and can also procure the goods and services it desires (Okwu et al., 2013). According to Krueger (1983), a country enjoys high earnings from exports and the effect thereof is to have high economic growth through increased production. Spence (1997) argues that the Government must play a significant role with export promotion by providing economic instruments to industries for the promotion of the national exports. A country will enjoy a successful export promotion strategy if there is in place, well-defined trade policies. Governments also need to provide assistance to national industries to tackle barriers, locally and internationally (Cavusgil, 1983). Export promotion has been viewed to be distinct to countries and there are no universal arrangements stipulating the extent of the state's involvement in the promotion (Pointon, 1978). Second, one of the reasons for export promotion strategy is to grow the sales of products produced domestically in the international markets. There is efficient resource allocation in export promotion strategy unlike import substitution industrialization. The nation adopting export promotion strategy must utilize its available resources in such a way that products will be manufactured to meet the 
international demand and to meet its international opportunity costs (Bhagwati, 1988). For the last few decades, the focus of states has been on export strategies since there is evidence of improved economic development in nations engaged in export promotion. Nations are now opening their economies for open markets and free trade to increase competition.

Some have however argued that government interventions do not necessarily improve export performance, rather market forces have placed national industries in a competitive position. Further, there are no reliable statistics to justify economic growth from exports in these countries (Nothdurft, 1992). Bhagwati (1988) also argues that there are activities associated with export promotion strategies that are geared towards high-yielding profit and rent-seeking by diverting resources from productive use into unproductive use. They are rather directed at profitable lobbying to change policies or to evade them or to seek revenue and this is a loss to the state (Bhagwati, 1988).

\section{EVALUATION OF THE SUCCESSES AND FAILURES OF THE EXPORT PROMOTION STRATEGY IN SELECTED SOUTHEAST ASIAN COUNTRIES}

The Southeast Asian region comprises of ten countries, and they are members of the Association of Southeast Asian Nations (ASEAN). Malaysia, Indonesia, Philippines, Singapore, Thailand, Laos, Cambodia. Myanmar, Brunei and Vietnam are the members of ASEAN. Economies like Indonesia, Malaysia, Singapore and Thailand have recorded rapid economic growth over the last 40 years whilst others like Laos and, Philippines have been comparatively average (Anaman, 2006). The economic growth seen in Southeast Asia has primarily been based on collaboration between the private sector and the state (Anaman, 2006). Governments in this region provided economic instruments such as credit and subsidies to push the export promotion agenda (Bora et al., 2000). The Southeast Asian countries were considered to be successfully exporting manufactured products to the international market. It is an undeniable fact that the developing countries of Southeast Asia are among the most successful exporters of manufactured goods within the Third World (Lutkenhorst, 1984). Largely, this region has been attributed with the dynamic and gradual development of international division of labor. These countries moved from the traditional structure of development of just relying on raw and unprocessed agricultural products to achieve economic growth to a more diverse economy based on exportation. The Southeast Asian countries adopted strategies to promote export growth by a mixture of permissive and positive functional policies (Bora et al., 2000). The permissive policies meant these countries adopted macroeconomic policies that promoted exports which gave them more profit than even their internal sales. Industries that were into exports as a result, had confidence to continue with exportation of products. Predictability and stability in exchange rates and market systems also encouraged exportation in these Asian countries. Export incentives were given by the governments to support exports trade, tax privileges and subsidies (Bora et al., 2000).

Factors leading to market failures were tackled with the positive functional support. The nations provided physical infrastructure mainly for promotion of exports. Originally, the populace of the original Tigers had a high illiteracy rate and as part of the positive functional policies, they invested in educating and training of the people particularly in Indonesia (Bora et al., 2000). In Malaysia, employees particularly in the electronics industry were trained to help the country attain industrialization. Credit was easily accessible in this region especially in Singapore and this helped 
promote internal export industries and attract foreign investment. Small and Medium-Sized Enterprises (SMEs) had a boost from the state especially in Taiwan and Hong Kong as a result of special measures put in place by the state. These measures included giving tax incentives to bigger domestic companies that subcontract a portion of their works to SMEs to help the latter also develop and export. Policies that inhibited export promotion and favored import substitutes were abandoned. These mechanisms among others led to development in this Southeast Asian region and some have conceptualized it as the 'East Asian Miracle'. The strategies adopted by some of the Southeast Asian countries will be explained and an evaluation of the successes and failures of the export promotion strategy will be examined in the subsequent paragraphs.

\subsection{Export Promotion Strategy in Malaysia}

\subsubsection{Historical Antecedent of Export Promotion Strategy in Malaysia}

Before independence, the main products produced domestically were tin and rubber. Malaysia gained independence from Great Britain in 1957. Malaysia like other developing countries also applied the ISI strategy but for a short period. Before independence in1957, Malaysia was characterized by low income and the economy was highly rural and agricultural and they mainly produced tin and rubber. There were a lot of domestic small-scale businesses (Yusof \& Bhattasali, 2008). After independence, Malaysia launched an industrial policy which was mainly an inward looking strategy (import substitution policy). Fiscal incentives and tariffs were the major economic instruments to push this import industrial agenda. The Pioneer Industries Act 1957 stipulated for more protective barriers to protect new industries, and this led to high profit margins and spanned to the late 1960s (Jomo, 1993). Unfortunately, the projections on the rubber products plummeted due to competition from synthetic rubber (Yusof \& Bhattasali, 2008). Commencement of export promotion strategy took effect in 1968 through the promulgation of the Investment Incentives Act 1968. Tax incentives and tariffs that boosted the import substitution strategy became applicable to industries that were into exporting mainly the electronic industry. The Free Trade Zones (FTZs), for instance was established to evoke foreign investment through the production of goods for exports. Between 1970 and 2000, Malaysia experienced economic success through export promotion.

Another strategy was diversification of Malaysian's sources of income. The New Economic Policy formulated in 1969 during the Second Malaysia Plan (1971-75) was the launch pad for export promotion and this was applicable through to the Fifth Malaysia Plan (1986-1990). One of the major themes in this New Economic Policy was diversification of the sources of income for the economy of Malaysia (Yusof \& Bhattasali, 2008). The Malaysian government introduced urbanbased services and middle-skilled labor intensive industries which helped in reducing poverty. Education was upgraded and there was improved population health. Economic success in Malaysia between 1970 and 2000 cannot be underestimated but there were some challenges. Malaysia continued to depend on few export sectors including oil and gas, oil palm and electronics. This was not sufficient to push Malaysia into endogenous growth. From the 1980s, the attempt by Malaysia to be like Korea could not be materialized especially in the heavy and innovation-based industries sector. Malaysia was still vulnerable after year 2000 due to the rise of the manufacturing sector of China. Economic growth in Malaysia by then increased at a slow pace due to external competition from China. As a result, there was inequalities in income (Sachs, 2019). 


\subsubsection{Current Perspective of Export Promotion Strategy in Malaysia}

Despite the drawbacks, Malaysia continues to be a trading nation as it recognizes the relevance of free liberal trade to economic development. Malaysia's population in 2017 was 31.1 million (The World Bank, 2021a). Malaysia is currently the 19th largest export economy in the world according to the Economic Complexity Index. In 2017, Malaysia's exports (USD 263 billion) exceeded its imports (USD 197 billion). Positive trade balance of USD 66.4 billion. In 2017, the GDP of Malaysia was USD 314 billion (Observatory of Economic Complexity, 2019). In 2019, the main export products of Malaysia included integrated circuits, petroleum gas, palm oil, refined petroleum, semiconductor devices, rubber apparel, copper powder, asphalt mixtures and platinum clad metals (Observatory of Economic Complexity, 2019). In September 2020, the main exports were integrated circuits, palm oil, rubber apparel, refined petroleum and semiconductor devices (Observatory of Economic Complexity, 2020). The major export destinations of Malaysia include China, Singapore, United States of America, Japan and Hong Kong. Exports from Malaysia increased by $18.4 \%$ from a year earlier to MYR 95.6 billion (approximately USD 23.03 billion) in September 2021 far above market consensus of 14.6\% rise (Trading Economics, 2021).

However, despite this impressive growth rate of Malaysia, per the OECD Economic Surveys (2021), there are still social and governance challenges. For instance, registering a new business is still burdensome and fragmented, skills development opportunities are scarce for SME workers, insolvency regime creating a disincentive for entrepreneurs, adequate digital infrastructure is lacking, digital uptake is low among SMEs particularly e-commerce participation while the productivity gap between firms that use digital tools and firms that do not use them is large (OECD Economic Surveys, 2021).

\subsection{Export Promotion Strategy in Indonesia}

Indonesia was one of the countries that also adopted the import industrialization strategy with the hope of achieving economic growth during the 1970s (Ogujiuba et al., 2011). However, it was not enough as it led to unsatisfactory growth. Indonesia attempted to protect its infant industries by using the scarce available resources, but this strategy could not be used to match up the international competition. Indonesian government abandoned this inward looking strategy and shifted to export promotion strategy by mid 1970s (James et al., 1989). Although, the economy of Indonesia grew from this export promotion strategy, its GDP was still low. In addition, the contribution of exports to GDP was small in the 1970s. Indonesian government was pushed to adopt strategies geared towards economic growth.

Indonesia adopted some strategies. Export taxes were abolished in 1976 to attract investment in export industries. In addition, an indirect subsidy in the form of Export Certificate System was implemented in 1978 to favor exporting industries (James et al., 1989). Their currency, Rupiah was also devalued (James \& Fujita, 1989). Currently, Indonesia is the 25th largest country that is highly dependent on exports according to the Economic Complexity Index 2017 (Observatory of Economic Complexity, 2021). In 2017, Indonesia achieved a positive balance of trade as its exports were more than its imports. In 2017, Indonesia exported products worth USD 188 billion and imported goods worth an amount of USD 153 billion which culminated into an amount of USD 35.1 billion as trade balance. The products mainly exported by Indonesia include coal briquettes, 
petroleum gas, crude petroleum and rubber (Observatory of Economic Complexity, 2021). Indonesia is also dependent on the extraction and export of palm oil. Indonesia is the world's largest coal producer and dry fuel contributes to $14 \%$ of the country's exports (Clingendael, 2020). Since 2013, economic growth in Indonesia has been 5\% per annum and living standards in Indonesia has risen steadily (OECD Economic Surveys, 2018). Despite this growth, there is high unemployment rate, and most people are poor. There are corruption and inadequate infrastructure (OECD Economic Surveys, 2018). There is also inequality in resource distribution among the regions (Index Mundi, 2018a). But generally, it can be argued that export promotion strategy in Indonesia has been successful to a large extent.

\subsection{Export Promotion Strategy in the Philippines}

Philippines relies on wood industry, garments, travel goods, remittances and the communication equipment industry to attract export earnings (Statista, 2021; Calvelo, 2020). The Philippines just like the above mentioned Southeast Asian countries also practiced import substitution strategy as a move to attain economic development during the 1950s and 1960s (James et al.,1989). They also placed high import restrictions and huge tariffs on imported goods in a bid to reduce import consumption. This strategy could not help the Philippines to attain the expected growth, and this also led to high unemployment rate. The Export Incentive Act 1970 established the first export processing zone, and its emphasis was on export promotion in the Philippines. Despite this move, there was still bias towards domestic industries. In 1981, the government implemented the liberalization program which has helped attained to some extent, the economic growth needed in the Philippines.

\section{THE ISI EXPERIENCE OF GHANA DURING THE 1960s -1980s}

Ghana's population was 29,121,464 in 2017 (The World Bank Group, 2021b) which is close to the population of Malaysia in 2017. Ghana, Malaysia, Philippines and Indonesia are members of the World Trade Organization which advocates for free trade. Malaysia, Indonesia, Philippines and Ghana were after independence on August 31, 1957; August 17, 1945; July 4, 1946; and March 6,1957 , respectively classified as developing countries and they applied ISI at an early stage. It is apparent that Ghana is yet to reach the economic growth rate attained by Malaysia, Philippines and Indonesia and there are lessons to be learned by Ghana. Industrial development in Ghana has moved from import substitution industrialization to currently, a private sector led industrialization (Ackah et al., 2014). Before independence in 1957, Ghana's economy was small as it was mainly a manufacturing sector to serve domestic purposes. Its contribution was meagre in terms of economic growth. Industrialization became the focus of Dr. Kwame Nkrumah and his government (Convention People's Party) after independence to bring the nation to its economic growth destination (Killick, 2010). Government at the time considered industrialization to be a key factor in the modernization and development of the country. It was envisaged that the adoption of ISI would help remove price distortions, eliminate the cycle of poverty, create more jobs, and provide basic needs of Ghanaians (Killick, 2010). Policies were adopted to promote industrialization after independence. Ghana first adopted ISI by first setting up state owned manufacturing industries which were capital intensive. It focused on manufacturing consumer goods which were previously imported. There is less dependence on imported commodities which could be manufactured locally. There was also expansion in machinery industries. Nkrumah led industrialization was 
premised on socialism (Steel, 1972). Convention People's Party (CPP) Government focused also on the electrical, electronic and machinery industry so that these industries could assist in the industrialization process (Steel, 1972). There was significant growth in the industrial sector in Ghana during this era. The setting up of these manufacturing companies contributed to Ghana's gross manufacturing input. It contributed about 19\% of Gross manufacturing output. By 1962 and 1967, the Gross manufacturing output were $32 \%$ and $42 \%$ respectively by the state-owned industries. The output of the country expanded through the efforts of the state as well as privately owned enterprises (Steel, 1972).

However, the input needed to encourage the desired economic output did not materialize and according to Steel (1972), he argues that ISI may have been partly responsible for the decline. By 1970s, the ISI had evident setbacks including bottlenecks and balance of payments difficulties (Killick, 2010). From Busia's Government (1969-1972) to the National Redemption Council regime (1972-1975), they also faced economic downturn as a result of ISI. By the indications of World Bank, the ISI strategy was self-limiting (World Bank, 1985). ISI discouraged exports of manufactured products; this affected the country's foreign exchange. As a result, manufacturing industries could not get enough raw materials as raw materials produced in the country was inadequate to feed the many industries that were set up. Inadequate foreign exchange reserve meant that the country could not import the required raw materials to feed the established industries. The second challenging factor was that industries that depended on imports to make use of domestic resources became inefficient due to the lack of it (Steel, 1972).

In addition to this failure, Ghana experienced external shocks and unsuitable trade policies from the mid 1970s to 1983 . Ghanaian economy was severely affected as a result. One of the economic programs Ghana had to undertake in 1983 to reduce the economic difficulties in the country was Economic Recovery Program (ERP), a part of the Structural Adjustment Program (SAP). This program was intended to be used to stabilize the Ghanaian economy. The SAP/ERP sought to correct the structural macroeconomic imbalances of the previous decade by restructuring almost all sectors of the economy including industry (Steel, 1972). These included the introduction of market liberalization policies. Before the implementation of SAP, Ghana's gross domestic product (GDP) was consistently negative (Konadu Agyemang, 2000). Ghana suffered an "acute dislocation" when the colonial masters left the shores of the Gold Coast (Konadu-Agyemang, 2000). The British left behind an economy which was underdeveloped. The period before Ghana's independence was characterized by exploitation of raw materials in Ghana for external trade. Some have argued that despite these challenges, Ghana's economy was still in good condition relatively (Apter, 1972). By mid 1960s to 1980s, Ghana was in a staggering position to bankruptcy. This poor economy of the country was caused by endogenous factors among which were over-bloated public service, political instability, corruption and poor management of the economy (Huq, 1989). Ghana was in serious debt to various countries (Odutayo, 2015). The GDP of the Country fell within this period. The economy needed a revival and as a result, in 1983, the Bretton Wood institutions were invited by the then Provisional National Defence Council to help Ghana resuscitate its failing economy (i.e., IMF and World Bank) (Konadu-Agyemang, 2000). The prescription by the Bretton Wood agencies (i.e., IMF and World Bank) involved a "package of actions" (Konadu-Agyemang, 2000). These actions included the need for the government to cut expenditure on public service, health, and education, etc. (Konadu-Agyemang, 2000). It has been argued that Ghana benefitted from the implementation of SAP. The socio-economic position of 
the country improved considerably after the implementation of the SAP. The capacity of industries also improved. (Anyinam, 1994). The actions which led to an economic improvement of the country involved reducing the government's expenditure in social services and state-owned industries were also privatized in a bid to reduce government's expenditure (Watkins, 1995). As part of the economic growth, there was a boost in the production and exportation of non- traditional commodities like cocoa and timber which boosted the country's foreign exchange earnings. There was an uplift in the Gross National Investment from 3.6\% to 16\% during the 1980 s after the implementation of SAP. Inflation rate reduced from $73 \%$ to $13 \%$ within that period (Hutchful, 2002). The industrial capacity of Ghana experienced a surge from $25 \%$ to $46 \%$ within the $1980 \mathrm{~s}$ to early 1990s (Huchful, 2002).

\section{EXPORT PROMOTION STRATEGY IN GHANA}

By late 1980s to 2000, Ghana's trade policy under the ERP/SAP was to promote exports to achieve economic growth through private sector-led participation and promotion. Ghana's trade policy since 2004 to 2012 has been the promotion of the private sector which has been viewed to be the engine that drives growth (Kyerematen, 2004). In 2014, the Ministry of Trade and Industry led by Alan Kyerematen was focused on running two strategies which are an export-led and domesticled industrialization. The main products for exports in Ghana include cocoa beans, gold, diamonds, aluminum and tuna. The main export destinations of Ghana are Netherlands, Burkina Faso, South Africa and United Kingdom. Ghana's importation of products is mainly industrial supplies, capital and consumer goods and foodstuffs (Ghana Export Promotion Authority, 2017). Ghana imports these products from mainly China, United States, Belgium, United Kingdom and France. The Ghana National Medium Term Development Plan (NMTDP 2018-2019) is also one of the policy documents promoting exports in a liberalized and competitive market as a means to develop Ghana's economy (Ministry of Trade and Industry, 2017). The "One District One Factory" program is also an industrialization program aimed at promoting Ghana's industrialization agenda for economic development (Ghana Export Promotion Authority, 2017). It is anticipated that these factories under the One District One Factory to be established under this program will process "key indigenous product (s) of each district for development and promotion of the Export agenda" (Ghana Export Promotion Authority, 2017). The One District One Factory (1D1F) was launched in 2016 mainly with the aim of promoting rural industrialization. The vision is to change the economy from import dependency and the exportation of raw materials to an economy focused on manufacturing and adding value to raw materials for consumption and exports.

The industrialization program aims to cut down waste of raw materials (One District One Factory, 2021). The government aims to support this initiative in order to boost the economy. The government aims to create favorable environment to boost industrialization although the sector is private led. The program is private sector led albeit favorable environment created by the government to boost industrialization. The aim is for government to also provide favorable financial support to entrepreneurs who would want to establish companies to convert the raw materials into finished products. It is anticipated that Ghanaian companies will own and operate these factories they set up bearing all the risks and benefits. The objectives of the initiative are exploitation of the economic resource of each district and adding value to the raw resources they generate. Another objective is to guarantee that industries are spread across the districts to boost economic activity in all districts. Another objective is to generate employment opportunities for 
rural and peri-urban communities. The effect is that income levels and standard of living will increase. Rural-urban migration will be reduced significantly since the underlying cause is that rural people would want to seek greener pastures in the urban area. The initiative aims to promote export of these manufactured products in order to increase foreign exchange earnings. The production of substitutes for imported goods is also a way for the country to conserve its insufficient foreign exchange. The One District One Factory initiative is focused on moving the economy to an industrialized one and this will promote development.

Again, as part of the mandate of Ghana Export Promotion Authority, the National Economic Strategy was launched and the vision in this strategy is to pursue export diversification towards economic growth (Ministry of Trade and Industry, 2012). The National Export Strategy also aims to promote non-traditional export sector in Ghana since Ghana has the potential. These nontraditional export products include cocoa paste, veneer, canned tuna, natural rubber, yam, cashew nuts, and handicrafts and accounted for about $17.5 \%$ of the total export earnings (Osei-Assibey, 2015). In the year 2016 and 2017, Ghana's imports exceeded exports. For the year 2016 and 2017, Ghana's exports were worth USD 11.06 billion and USD 12.16 billion respectively. Imports for the same period was USD 12.75 billion and USD 12.73 billion respectively (Index Mundi, 2018b).

\section{RAMIFICATIONS OF COVID-19 ON EXPORTS}

The world is currently faced with COVID-19 pandemic, and it is a dire health crisis having economic implications across the globe. This pandemic has naturally forced the world to go into 'deglobalization' by compelling countries to close their borders to the world as well as limiting the movement of humans and goods thus affecting global economic activity (Baldwin \& di Mauro, 2020). According to Baldwin \& Tomiura (2020), COVID-19 pandemic is both a demand shock and a supply shock. The shock has significantly affected aggregate trade flows and likely to cause manufacturing distress as a result of international supply chain distortions (Asante-Poku \& van Huellen, 2021). The first quarter of the year 2020 suffered a 3\% decline in global trade, with estimated 20\% shrink in the second quarter (UNCTAD, 2020b). There is uncertainty about the future as to when the pandemic will end and its consequent economic crisis including private sector investment plans and foreign direct investments (UNCTAD, 2020b). In China, and other countries, some multinational companies have suspended productions since transport routes have been partially or fully down (Wilson, 2020). Debt positions of low- and middle-income countries have also been affected with limited access to concessional multilateral loans (UNCTAD 2019a; 2020a). These low- and middle-income countries generally depend on export commodities. Prices of commodities have been declining since 2018 with the latest blow being the COVID-19 crisis. Servicing of these debts have posed a challenge as a result (UNCTAD 2020b). Developing economies that depend on primary commodities have been hit the hardest since their economic growth is highly dependent on trade and foreign direct investments (Barua, 2020).

One of the ramifications of COVID-19 pandemic however has been a shift in users' needs and innovation owing to uncertainty about the future (Georgieva, 2020; Twilio, 2020). Countries are now innovating new actions for suitable products and services in line with the users' current needs (ADBI, 2020; Nalletamby, 2020). The need for appropriate products and services has also necessitated increasing collaboration and networking among various industries with a view of leveraging opportunities and mitigating risk. Digital trade is one of the actions to mitigate the 
economic slowdown caused by the pandemic. The importance of digital trade was apparent before the COVID-19 era, but it has become more beneficial during the COVID-19 pandemic due to various restrictions on movement across borders. (López \& Ferencz, 2018). Digitalization can help facilitate access to goods and services. Digital trade can play a role in supporting economic activity in times of confinement which may include promoting cross-border trade in digitally ordered parcels, adopting digital technologies at borders to enable efficient movement of goods, etc. (OECD, 2020). Although demand in products has been affected substantially, there is a shift in this pandemic driven environment for essential goods. Essential goods are those that are necessary for the sustenance of life including medicine, food, shelter, etc. People are also focused on saving money for health emergencies in this period of uncertainty (Barua, 2020). Demand for essential goods may increase whilst that of non-essential goods may decline in the global front.

In the ASEAN region, cooperation among member states has been robust as they currently have a COVID-19 framework (United Nations, 2020). The leaders of ASEAN nations with leaders of China, Japan and the Republic of Korea at a Special Summit on April 14, 2020, pledged to act jointly and decisively to control the spread of COVID-19 (ASEAN, 2020). The sectoral bodies under ASEAN are also committed to collective strategies to assuage the impact of the pandemic in various sectors including tourism, economy, health, agriculture etc. Distortions in demand and supply in goods and services have caused a decline in economic production in the sub-region (United Nations, 2020). For Malaysia, its GDP has declined owing to the COVID-19 pandemic which has affected its economy. The Malaysian economy contracted 5.6\% in 2020 which has been the worst performance of the country since the 1998 Asian Financial Crisis (Flanders Trade, 2021). Various sectors including hospitality, tourism, markets, retail, etc. have been affected (Flanders Trade, 2021). Merchandise trade including the extraction and export of palm oil has faced supply chain disruptions due to lockdowns and quarantine measures. The Malaysian government has announced many attractive tax incentives for the manufacturing sector including the pharmaceutical sector. The ramifications on COVID-19 pandemic have also triggered the Malaysian government's actions in ensuring the supply of essential goods such as food, medicine etc. Malaysia was heavily dependent on its oil and gas sector, but the pandemic has triggered the need for diversification into health and medical industry, food and beverage industry etc. (Flanders, 2021).

Indonesia is also heavily dependent on extraction and export of palm oil. Indonesia also experienced a decline in palm oil exports as a result of COVID-19 pandemic and its consequences on the global economy (Clingendael, 2020). The decline in demand in food and hospitality industry in some Asian markets also affected palm oil consumption. For instance, there was a drop in palm oil demand by China, Europe and India who are Indonesia's largest palm oil importers because there were national lockdowns in these jurisdictions (Clingendael, 2020). There were also logistical interruptions and transport disruptions because of lockdowns (Biofuels International, 2020). Again, Indonesia's coal and dry fuel industry which contributes about $14 \%$ of its exports was hit hard by the decline in international trade. In a bid to rejuvenate its economy, Indonesia has joined the International Coordination Group on COVID-19, facilitated by Canada, to stimulate free trade through the pandemic. The purpose of joining the Group is to identify various sectors for collaborative actions such as "maintaining an open flow of trade, securing value chains and restoring the post-pandemic global economy' (Septiari, 2020). Indonesia intends to diversify its export markets to other jurisdictions in Africa and South America. 
Philippines relies on remittances and has also been hit thus reducing consumption and investment. Again, the communication equipment industry in the Philippines is estimated to lose USD 115 million from a two percent cut in China exports of intermediate inputs (Statista, 2021). Again, the garments, travel goods and wood industries were also hit as a result of the lockdown restrictions and weak global demand. The USD 105.8 billion 2020 target before COVID-19 was not achieved since goods and services exports declined to USD 80.5 billion (Calvelo, 2020). According to Indonesia's Department of Trade and Industry, a stronger support to 'the private manufacturing and services industries and collaboration are needed to work on achieving the fighting targets set' (DTI, 2020).

In view of these developments pre and during COVID-19 era, there are lessons for Ghana from the experiences of these selected Southeast Asian countries. A historical and current perspective of ISI and export promotion in Ghana will be explained in the subsequent paragraphs.

\section{LESSONS FOR GHANA FROM THE EXPERIENCE OF SELECTED SOUTHEAST ASIAN COUNTRIES}

Clearly, the policies in Ghana regarding export promotion are quite friendly when it comes to promotion of exports in Ghana but there are still challenges more so in the era of COVID-19 pandemic. Ghana's export composition is highly dependent on primary commodities. Gold, oil, and cocoa contribute over 80\% of all export earnings in 2018 (Aman, 2020). Ghana is therefore a commodity dependent country (UNCTAD, 2019b). Such commodity chains are most vulnerable to demand and supply shocks from impacts of global activity and disruptions (Aman, 2020). These global disruptions affect the revenue of the state. The cocoa industry in Ghana for instance has been hit hard because spraying and fertilizer programs were delayed (UNCTAD, 2019b). This has consequent effect on future harvests. COVID-19 clearly has long term adverse effects on countries that depend on commodity earnings such as Ghana. There are challenges faced by Ghana's export sector making it inefficient in contributing to national economic development. Per the experiences of selected Southeast Asian countries, Ghana may emulate from them to achieve economic growth pre and during COVID-I9 era and these are further explained.

\section{Developing Infrastructural Capacity}

First, the government of Ghana needs to put in place measures to fill up the infrastructure gap the country faces. There are generally poor roads, energy problems, inadequate storage and cold chain facilities, etc. (Osei-Assibey, 2015). This becomes a disincentive for exporting industries in the country. Examples from these Southeast Asian countries clearly indicate a boost of their exports as a result of government's intervention in providing and investing in good infrastructure. It has been argued that markets connectivity and trade promotion are dependent to some extent on availability of infrastructure (Rehman et al., 2020). According to Ismail (2015) and MartinezZarzose \& Suarez-Burguet (2007), the lack of infrastructure leads to reduction in profits, causes unnecessary delays and also increases the cost of production. In Malaysia, there are favorable regulatory conditions and a financial sector that promotes investment in infrastructure with a view of promoting economic growth (Global Infrastructure Hub, 2021). Malaysia has a history of infrastructure development to boost economic growth as evidenced in the Second, Third and Fourth Malaysian Plan of 1971-1975, 1976-1980 and 1981-1985, respectively. By the Fourth 
Malaysian Plan, there was a rapid expansion in road networks by $49 \%$, port handling capacity by $122 \%$ and electricity generation capacity by $76 \%$. This trend of expansion has continued to subsequent years (Lee, 2011).

Ghana has for the past few years experienced erratic power supply and this does not augur well for export promotion. There is no efficient and dedicated transportation system in Ghana especially with the rail system to link up the various regions to the largest port known as Port of Tema. This invariably impedes competition. Perishable goods generally get destroyed because of challenges with the transportation system. The Boankra Port in Ashanti Region has still not been completed to help reduce the congestion at Port of Tema. It is therefore imperative that the government provides support in the form of good infrastructure to aid export promotion as envisaged in the National Export Strategy and other policy documents. There is also the need for adequate digital infrastructure in view of the COVID-19 pandemic (OECD Economy Survey, 2021).

\section{Financial and Tax Incentives}

Again, there is difficulty in accessing finance by exporters and the interest rate in Ghana is high as compared to the referenced Southeast Asian countries. Malaysian and Indonesian government provided cheap loans to industries that were willing to engage in exports business. Lack of access to finance becomes a challenge to expand production. Financial institutions more especially banks are also reluctant to provide affordable credit to agricultural producers and exporters because of volatile macroeconomic environment (Osei-Assibey, 2015). In addition, there must be financial incentives for these promoters in Ghana through subsidies, tax rebates, quotas, etc. (Osei-Assibey, 2015). These economic instruments need to be favorable to support the export industry more so in the COVID-19 era in order to improve liquidity. In the COVID-19 era, Malaysia has for instance, introduced tax incentives for non-traditional sectors of the economy including the pharmaceutical sector in order to boost exports. This is in response to the current needs of users across the globe (Flanders Trade, 2021). Ghana may also emulate this by granting tax incentives to other sectors other than commodity sector in order to gain export earnings in this uncertain period.

\section{Diversification of Exports and Markets}

In addition, the government can learn from the experience of the Southeast Asian countries to help stabilize the macroeconomic indicators and this will in turn reduce the high interest rates. There must also be diversification of the market in terms of products and destinations. The non-traditional products have a potential and Ghana can obtain huge receipts from same especially in this COVID19 era. Southeast Asian countries like Indonesia and Malaysia developed their economy by encouraging the export of Non-traditional products like palm oil (ISSER, 2013) and now in the COVID-19 era, on pharmaceutical and other essential products. The demand for essential goods in the COVID-19 era has increased (Barua, 2020). In diversification of exports, Ghana may look at essential goods and not necessarily, commodity exports only. Indonesia also intends to diversify its export markets to other jurisdictions in Africa and South America as a result of the economic implications of the pandemic (Septiari, 2020).

\section{Innovation and Collaboration}


Governments are implementing measures including developing digital technologies to create enabling conditions for resilience during pandemic (Nalletamby, 2020; López \& Ferencz, 2018). The pandemic has affected cross-border trade and transport owing to restrictions imposed by various countries (United Nations, 2020). Innovations to trade are important in this era as a result of the restrictions. Innovations include digital trade connectivity as this is important for the 'agility of supply chains during the COVID-19 era' (OECD, 2020). COVID-19 has highlighted the importance of science, technology and innovation in adapting to the new digitalized global economy (UNCTAD, 2021a). Again, collaboration among various industries and the government would open more opportunities for the export sector whilst mitigating risk in this uncertain time. Collaboration will aid in maintaining an open flow of trade and secure value chains (Septiari, 2020).

\section{Building Human Capacity}

Before COVID-19 pandemic, countries such as Singapore and Malaysia as part of their industrialization policy trained their populace to equip them with necessary skills. Education was upgraded in these countries. Exporters in these countries acquired the skills and knowledge to exploit the opportunities available in the world market. It is argued that poor knowledge in the export business is detrimental in the long run and economic growth may be hugely affected. Currently, COVID-19 pandemic has also affected trade. One ramification of COVID-19 is digitalization of trade. Worldwide, digitally deliverable services went from below $52 \%$ of services exports in 2019 to almost 64\% in 2020. Digital technologies also played an important role in supporting broader international trade and economic activity in 2020. There is an increasing reliance on digital delivery to continue trade despite restrictions on movement due to the pandemic (UNCTAD, 2021a). Developing productive capacities including human capacity is necessary to diversify an economy. Limited human and industrial capacity have contributed to the vulnerabilities in developing economies (UNCTAD, 2021b). Ghana may train its exporters and other stakeholders on the new normal which is digital trade to meet global opportunities in this COVID-19 era.

\section{Favorable and Consistent Trade Policies}

Again, cumbersome trade policies and procedures create bottlenecks in the system. Bottlenecks impedes the fluidity of export products movement (Osei-Assibey, 2015). Major barriers to fluid movement of goods and services include cumbersome trade policies, procedures, practices, and high transaction costs. It has been argued that favorable and consistent trade policies increases exporter competitiveness (Lall, 1997). Incentives such as tax privileges and subsidies may also improve export profitability. One of the major problems of Non-Traditional Agricultural export producers is the land tenure systems in Ghana. Mainly in Ghana, the allodial interest in land resides in the stools, families and individuals (Adjei, 2015). There are sometimes disputes among these landowners and it poses a challenge when an exporter needs a large tract of land to grow these non-traditional crops to sustain the huge global demand (Osei-Assibey, 2015). The Government of Ghana through favorable policies may aid in the acquisition process so that exporters can meet the export demands.

\section{CONCLUSIONS}


It can be argued that Import substitution industrialization played a significant role in most Latin American nations and developing nations after the Second World War as a strategy to economic development. It was however inefficient in helping countries achieve the desired economic development. The success story of Taiwan, Tanzania and South Korea helped develop interest in export promotion strategy as these countries were doing well economically despite the challenging times. The Asian Tigers also applied this export promotion strategies and attained tremendous economic development. It has been argued that export promotion strategy will be efficient if there is proper analysis and exports are based on the potential of the country. This would include identifying the resources available to the country and the markets most suitable and available for its production. It may be viewed from the examination so far, that export promotion in the Southeast Asian countries was dependent on favorable trade policies. The success of these countries did not happen spontaneously. However, the economic growth was as a result of the role the governments played in promoting exports. The economic growth of these states was not only based on the normal demand and supply forces but through a concerted effort. There were some challenges but in general terms, the adoption of the export promotion strategy was a success. COVID-19 pandemic has also brought the world to its knees especially with the associated economic implications. Various countries including Malaysia, Indonesia and Philippines have implemented new measures to meet their export earning targets which may be emulated by Ghana. There were policies in place to aid export promotion in Ghana pre COVID-19 era albeit the challenges faced. It may be argued that Ghana can improve on its export promotion strategy by drawing lessons from these Southeast Asian countries. Ghana therefore needs to develop its infrastructural capacity, improve its financial and tax incentives, diversify its markets and exports, develop digital technologies and innovations, build the country's human capacity, and also develop favorable and consistent trade policies.

\section{REFERENCES}

Ackah, C. G., Adjasi C. K., \& Turkson, F. (2014). Scoping Study on the Evolution of Industry in Ghana. World Institute for Development Economics Research Working Paper 2014/075, 1-39 https://doi.org/10.35188/UNU-WIDER/2014/796-7

ADBI. (2020, July 10). ADBI Dean Urges Global Support for Digitalization-Based Recovery. ADBI News Release. https://www.adb.org/adbi/news/adbi-dean-urges-global-supportdigitalization-based-recovery

Adjei, D. D. (2015). Land Law, Practice and Conveyancing in Ghana. Adwinsa Publications (Gh.) Ltd

Aman, S. (2020, April 30). Covid-19 and Ghana: A Macroeconomic Impact Assessment. International Development Program. http://www.saisperspectives.com/covid19pandemic/2020/4/30/covid-19-and-ghana

Anaman, K. A. (2006). Economic and Social policies of Dynamic Southeast Asian Countries: How applicable are they to Ghana and Africa? The Institute of Economic Affairs, 1-44. https://www.africaportal.org/publications/economic-and-social-policies-of-dynamicsoutheast-asian-countries-how-applicable-are-they-to-ghana-and-africa/

Anyinam, C. (1994). Spatial Implications of Structural Adjustment Programmes in Ghana. Tijdschrift Voor Economische En Sociale Geografie, 85(5), 446-460. https://doi.org/10.1111/j.1467-9663.1994.tb00703.x

Apter, D. E. (1972). Ghana in Transition. Princeton University Press 
Asante-Poku, N. A., \& van Huellen, S. (2021). Commodity exporter's vulnerabilities in times of COVID-19: the case of Ghana. Canadian Journal of Development Studies, 42(1-2), 122144. https://doi.org/10.1080/02255189.2020.1857225

ASEAN. (2020). Declaration of the Special ASEAN Summit on Coronavirus Disease 2019 (COVID-19). ASEAN. https://asean.org/storage/2020/04/FINAL-Declaration-of-theSpecial-ASEAN-Summit-on-COVID-19.pdf

Balassa, B. (1992). Economic Integration in Eastern Europe. Structural Change ad Economic Dynamics, $3(1)$,

3-15. https://www.sciencedirect.com/science/article/abs/pii/0954349X9290023Y

Baer, W. (1972). Import Substitution and Industrialisation in Latin America: Experiences and Interpretations. Latin American Research Review, 7(1), 95-122. https://edisciplinas.usp.br/pluginfile.php/5896639/mod_folder/content/0/Pol\%C3\%ADtic a $\% 20$ Externa $\% 20$ Brasileira/Import $\% 20$ Substitution $\% 20$ and $\% 20$ Industrialization $\% 20 \mathrm{in} \%$ 20Latin\%20Amercia\%20Experiences\%20and\%20Interpretations.pdf?forcedownload=1

Baldwin, R., \& di Mauro, B. W. (Eds.). (2020). Economics in the Time of COVID-19. Centre for Economic Policy Research. https://voxeu.org/system/files/epublication/COVID-A19.pdf

Baldwin, R., \& Tomiura, E. (2020). Thinking ahead about the trade impact of COVID-19. In Baldwin, R. \& di Mauro, B. W., Economics in the Time of COVID-19. Centre for Economic Policy Research, 59-72

Barua, S. (2020). Understanding Coronanomics: The economic implications of the coronavirus (COVID-19) pandemic. SSRN. https://ssrn.com/abstract=3566477

Bhagwati, J.N. (1988). Export-Promoting Trade Strategy: Issues and Evidence. Oxford University Press.

Bhagwati, J. N. (1986). Export Promoting Trade Strategy: Issues and Evidence. The World Bank. https://www.jstor.org/stable/3986522

Biersteker, T.J. (1980). Self-Reliance in Theory and Practice in Tanzanian Trade relations. University of Wisconsin Press

Biofuels International. (2020, April 7). Palm Oil prices to fall amid coronavirus uncertainty global. Biofuels International. https://biofules-news.com/news/palm-oils-prices-to-fallamid-coronavirus-uncertainty-globally

Bora, B., Lloyd P.J., \& Pangestu, M. (2000). Industrial Policy and the WTO. United Nations Conference on Trade and Development-Policy Issues in International Trade and Commodities Study Series No.6

Bruton, H. J. (1998). A Reconsideration of Import Substitution. Journal of Economic Literature, XXXVI, 903-936

Calvelo, G. (2020, January 4). Philippines cuts exports targets due to COVID-19 impact. ABSCBN News. https://news.abs-cbn.com/business/01/04/21/philippines-cuts-export-targetsdue-to-covid-19-impact

Cavusgil, S.T. (1983). Policy Implications of Research on the Export Behaviour of Firms. Akron Business and Economic Review, 14(2), 16-22

Clingendael. (2020, June 22). The impact of COVID-19 measured on Indonesian value chains. Netherlands Institute of International Relations. https://www.clingendael.org/publication/impact-covid-19-measures-indonesian-valuechains 
DTI. (2020, January 4). DTI reviews medium-term export targets amid COVID-19 pandemic effects. Department of Trade and Industry of the Republic of the Philippines. https://www.dti.gov.ph/archives/news-archives/medium-term-export-targets/

Flanders Trade. (2021, November 10). Coronavirus -The situation in Malaysia. Flanders Trade. https://www.flandersinvestmentandtrade.com/export/nieuws/coronavirus- $\% E 2 \% 80 \% 93$ situation-malaysia

Georgieva, K. (2020, July 22). Strategy of Recovery: A Conversation with IMF Managing Director Kristalina Georgieva- A Virtual Event hosted by Réka Szemerkényi of the Center for European Policy Analysis (CEPA). Center for European Policy Analysis. https://www.google.com/url?sa $=t \& r c t=j \& q=\&$ esrc $=$ s\&source=web\&cd $=\& c a d=r j a \& u a c t=$ 8\&ved=2ahUKEwiXiai9zMf0AhUMzIUKHXwNBHUQwqsBegQIAhAB\&url=https\%3 $\mathrm{A} \% 2 \mathrm{~F} \% 2 \mathrm{Fm}$.facebook.com\%2Fimf $\% 2 \mathrm{Fvideos} \% 2 \mathrm{Fstrategy-of-recovery-a-conversation-}$ with-imf-managing-director-kristalinageorgi\%2F747554565999223\%2F\&usg=AOvVaw1kkxwk_MhjFEsVrpLu6XAN

Ghana Export Promotion Authority. (2017). National Export Strategy: One District, One Exportable Product. GEPA https://www.gepaghana.org/national-export-strategy-onedistrict-one-exportable-product/

Global Infrastructure Hub. (2021). Malaysia. https://infracompass.gihub.org/ind_country_profile/mys/

Hira, A. (2007). Did ISI fail and is neoliberalism the answer for Latin America? Re-assessing common wisdom regarding economic policies in the region. Brazilian Journal of Political Economy, $27(3)$

345-356. https://www.scielo.br/j/rep/a/pXGCjxCZcSLXPfN4p3fMhsJ/?lang=en\#

Huq, M. M. (1989). The Economy of Ghana: The First 25 years. Macmillan

Hutchful, E., \& United Nations Research Institute for Social Development. (2002). Ghana's Adjustment Experience: The Paradox of Reform. Unrisd

ISSER (2013). The State of the Ghanaian Economy. University of Ghana

Ismail, N. W. (2015). The Impact of Infrastructure on Trade and Economic Growth in Selected Economies in Asia. ADBI Working Paper Series, No. 553. https://www.adb.org/sites/default/files/publication/177093/adbi-wp553.pdf

Index Mundi. (2018a). Indonesia Economy Profile. https://www.indexmundi.com/indonesia/economy_profile.html

$\begin{array}{lllll}\text { Index } & \text { Mundi. (2018b). Ghana Economy Profile } 2018 .\end{array}$ https://www.indexmundi.com/ghana/economy_profile.html

James, W.E., Naya, S., \& Meier G. M. (1989). Asian Development: Economic Success and Policy Lessons. University of Wisconsin Press

James, W. E., \& Fujita, N. (1989). Import Substitution and Export Promotion in the Growth of the Indonesian Industrial Sector. ASEAN Economic Bulletin, 6(1), 59-70. http://www.jstor.org/stable/25770232

Jomo, K. S. (Ed.). (1993). Industrializing Malaysia: Policy, Performance and Prospects. Routledge

Killick, T. (2010). Development and Economics in Action: A Study of Economic Policies in Ghana. Routledge

Kokko, A. (2002). Export-Led Growth in East Asia: Lessons for Europe's Transition Economies. Working Paper No. 142. http://pure.iiasa.ac.at/id/eprint/6678/ 
Konadu-Agyemang, K. (2000). IMF and World Bank Sponsored Structural Adjustment Programs in Africa: Ghana's Experience, 1983-1999. Aldershot: Ashgate

Kyerematen, A. (2004). Ghana Trade Policy. Ministry of Trade and Industry. https://moti.gov.gh/docs/Ghana_Trade_Policy.pdf

Krueger, A. O., \& Tuncer, B. (1982). An Empirical Test of the Infant Industry Argument. The American Economic Review, 72(5), 1142-1152. http://links.jstor.org/sici?sici=00028282\%28198212\%2972\%3A5\%3C1142\%3AAETOTI\%3E2.0.CO\%3B2-5\&origin=repec

Krueger, A. (1983). Export Promotion: A Catalyst to Diversification of Productive in Developing Economies. Department of Trade and Industry, South Africa

Lall, S. (1997). Selective Policies for Export Promotion. United Nations/World Institute for Development Economic Research

Lee, C. (2011). Infrastructure and economic development. University of Wollongong, 423-436 https://ro.uow.edu.au/commpapers/788

List, F. (1841). National System of Political Economy. Origami Books

López, G. J., \& Ferencz, J. (2018). Digital Trade and Market Openness. OECD Publishing. https://dx.doi.org/10.1787/1bd89c9a-en on 15/07/2021

Lutkenhorst, W. (1984). Import Restrictions and Export Promotion Measures in Southeast Asian countries: Recent developments and future perspectives. ASEAN Economic Bulletin, 1(1), 43-69. https://www.jstor.org/stable/i25770002

Martinez-Zarzose, I., \& Suarez-Burguet, C. (2007). Transport costs and trade: empirical evidence for Latin American imports from the European Union. The Journal of International Trade \& Economic Development, 353-371. https://doi.org/10.1080/09638190500212121

Ministry of Trade and Industry. (2017). Medium Term Expenditure Framework (MTEF) For 20182021. MOTI. https://www.mofep.gov.gh/sites/default/files/pbb-estimates/2018/2018PBB-NCCE.pdf

Ministry of Trade and Industry (2012). Ghana National Export Strategy for the Non-Traditional sector (2013-2017).

MOTI. https://www.moti.gov.gh/docs/NATIONAL\%20EXPORT\%20STRATEGY.pdf

Nalletamby, S. (2020, April 16). COVID-19 pandemic bolsters case for technology-based economic resilience. African Development Bank (AfDB).

https://www.afdb.org/en/news-and-events/covid-19-pandemic-bolsters-case-technology-basedeconomic-resilience-35255 on 13/07/2021

Nothdurft, W.E. (1992). Going Global: How Europe Helps Small Firms Export. Brookings

Observatory of Economic Complexity. (2020). Malaysia. OEC. https://oec.world/en/profile/country/mys

Observatory of Economic Complexity. (2021). Indonesia. OEC https://legacy.oec.world/en/profile/country/idn/

Observatory of Economic Complexity. (2019). Malaysia. OEC. https://oec.world/en/profile/country/mys?exportServices YearsSelector=ServiceYearFlow 218\&yearSelector1=exportGrowthYear23\&yearSelector2=importGrowthYear23

Odutayo, A. (2015). Conditional Development: Ghana Crippled by Structural Adjustment Programmes. E-International Relations. https://www.e-ir.info/2015/03/01/conditionaldevelopment-ghana-crippled-by-structural-adjustment-programmes/

OECD Economic Surveys. (2021). Malaysia. OECD. https://www.oecdilibrary.org/sites/cc9499dd-en/index.html?itemId=/content/publication/cc9499dd-en 
OECD. (2020). Leveraging digital trade to fight the consequences of COVID-19. OECD https://www.oecd.org/coronavirus/policy-responses/leveraging-digital-trade-to-fight-theconsequences-of-covid-19-f712f404/

OECD Economic Surveys. (2018). Indonesia. $\quad$ OECD https://www.oecd.org/eco/surveys/economic-survey-indonesia.htm

OECD. (1984). Competition and Trade Policies: Their Interaction. OECD Publishing

Ogujiuba, K., Nwogwugwu, U., \& Kike, E. (2011). Import Substitution Industrialization as Learning Process; Sub-Saharan African Experience as distortion of the "Good". Business and Management Review, 1(6), 8-21. https://mpra.ub.uni-muenchen.de/102316/

Okwu A. T., Dada, S. O. \& Owolabu, S. A. (2013). A comparative analysis of export promotion strategies in selected African Countries (South Africa, Nigeria and Egypt). International Journal of Management Sciences, 1(6), 204-211. https://econpapers.repec.org/RePEc:rss:jnljms:v1i6p2

One District One Factory. (2021). Background and Context. Ministry of Trade and Industry. https://www.moti.gov.gh/1d1f/about.php

Osei-Assibey, E. (2015). Export Promotion in Ghana. African Center for Economic Transformation

Pointon, T. (1978). Measuring the Gains from Government Export Promotion. European Journal of Marketing, 12(6), 451-462. https://doi.org/10.1108/EUM0000000004977

Prebisch, R. (1950). The Economic Development of Latin America and its principal problems. United Nations Department of Social Affairs

Rehman, F. U., Noman, A. A., \& Ding, Y. (2020). Does infrastructure increase exports and reduce trade deficit? Evidence from selected South ASIAN countries using a new Global Infrastructure Index. Journal of Economic Structures, 9(10). https://doi.org/10.1186/s40008-020-0183-x

Sachs J.D. (2019). Malaysia's Structural Economic Change: Past, Present and Future. Economic History of Malaya. https://www.ehm.my/publications/articles/malaysias-structuraleconomic-change-past-present-and-future

Schmitz, H. (1984). Industrialisation strategies in less developed countries; some lessons of historical perspective. The Journal of Development Studies, 21(1), 1-21. https://doi.org/10.1080/00220388408421928

Septiari, D. (2020, April 19). Indonesia, 12 Cross-region countries agree to keep supply chains open. TheJakartaPost. https://thejakartapost.com/news/2020/04/19/indonesia-12/crossregion-countries-agree-to-keep-supply-chains-open.html

Severns, C. (2021, March 6). The Development of the Four Asian Tigers. Borgen Magazine https://www.borgenmagazine.com/development-of-the-four-asian-tigers/

Spence, M.M. (2000). Critical Considerations for Governments Programmes Evaluation. http://dx.doi.org/10.20381/ruor-1354

Statista. (2021). Estimated economic trade impact from Chinese supply disruptions due to the coronavirus COVID-19 pandemic in the Philippines in 2020, by industry. Statista Research Department.https://www.statista.com/statistics/1104369/philippines-economic-tradeimpact-from-china-due-to-the-coronavirus-covid-19-pandemic-by-industry/

Steel, W.F (1972). Import Substitution and Excess Capacity in Ghana. Oxford Economic Papers, New Series 
Stern, R.E. (1997). Foreign Direct Investment, Exports and East -West Integration: Theory and Practice. In R.N. Cooper and J. Gacs (Eds.), Trade Growth in Transition economies: Export Impediments for Central and Eastern Europe. Edward Elgar

Thee, K. W. (1984). Japanese Direct Investment in Indonesian Manufacturing. Bulletin of Indonesian Economic Studies, 20(2), 90-106. https://www.tandfonline.com/doi/abs/10.1080/00074918412331334622

The World Bank. (2021a). Population. Total- Malaysia. https://data.worldbank.org/indicator/SP.POP.TOTL?locations=MY

The World Bank Group. (2021b). Population, total- Ghana. https://data.worldbank.org/indicator/SP.POP.TOTL?locations=GH

Trading Economics. (2021). Malaysia Exports. https://tradingeconomics.com/malaysia/exports

Twilio (2020). COVID-19 Digital engagement report. Twilio. https://www.twilio.com/covid-19digital-engagement-report

UNCTAD. (2021a). Trade data for 2020 confirm growing importance of digital technologies during COVID-19. UNCTAD. https://unctad.org/news/trade-data-2020-confirm-growingimportance-digital-technologies-during-covid-19

UNCTAD. (2021b). UNCTAD15: Building resilience key to prosperity for all in post-COVID-19 world. UNCTAD. https://unctad.org/news/unctad15-building-resilience-key-prosperityall-post-covid-19-world

UNCTAD. (2020a). From the Great Lockdown to the Great Meltdown: Developing Country Debt in the Time of Covid-19. Trade and Development Report Update April 2020. UNCTAD. https://unctad.org/en/PublicationsLibrary/gdsinf2020d3_en.pdf

UNCTAD. (2020b). Impact of the Coronavirus Outbreak on Global FDI. Investment Trends Monitor, Special Issue. UNCTAD. https://unctad/org/en/PublicationsLibrary/diae gitm34 coronavirus 8march2020.pdf

UNCTAD. (2019a). Financing a Global Green New Deal.” Trade and Development Report 2019. UNCTAD. https://unctad.org/en/PublicationsLibrary/tdr2019_en.pdf

UNCTAD. (2019b). State of Commodity Dependence 2019. UNCTAD. https://unctad.org/en/PublicationsLibrary/ditccom2019d1_en.pdf

United Nations. (2020). Policy Brief: The Impact of COVID-19 on South-East Asia. United Nations. https://unsdg.un.org/resources/policy-brief-impact-covid-19-south-east-asia

Vaz, P. H. \& Baer, W. (2014). Real exchange rate and manufacturing growth in Latin America. Latin American Economic Review, 23(1), 1-17

Watkins, K. (1995). The Oxfam Poverty Report. Oxfam

Westphal, L.E., (1982). Fostering Technological Mastery by Means of Selective Infant-Industry Protection. In Moshe Syrquin and Simon Teitel (Eds.), Trade, Stability, Technology and Equity in Latin America. Academic Press

Wilson, A. (2020, March 24). Coronavirus travel updates: which countries have restrictions and FCO warnings in place. The Guardian. https://www.theguardian.com/travel/2020/mar/24/coronavirus-travel-updates-whichcountries-have-restrictions-and-fco-warnings-in-place

World Bank. (1985). World Development Report. Oxford University Press. https://openknowledge.worldbank.org/handle/10986/5968

Yusof, Z.A., \& Bhattasali, D. (2008). Economic Growth and Development in Malaysia: Policy Making and Leadership. The World Bank Group. https://openknowledge.worldbank.org/handle/10986/28046?locale-attribute=en 